\title{
APPLICABILITY OF CONSOLIDATED TECHNIQUES IN THE VIEW OF ROMANIAN ACCOUNTING REGULATIONS
}

\author{
Roşu Cristina \\ "Vasile Alecsandri" University of Bacău \\ cristinaciuraru@yahoo.com
}

\begin{abstract}
The accounting regulations are more and more interested in groups of companies. In some cases, these regulations require for preparing the consolidated financial statements. This is the task of the parent company who keeps the consolidated accounts. To accomplish its goals, the consolidated accounting uses a couple of, so-called, consolidation techniques. These are applied in the case of groups of companies with a complex structure. Their goal is to elaborate the consolidated financial statements using a set of methods and empirical skills. In this article we synthesize and apply the consolidation techniques in the view of Romanian accounting regulations. The Romanian practice has revealed, especially, two techniques: one based on direct consolidation and another one based on multiple levels (phased consolidation). Therefore, this work regards only the technical side of consolidated accounting, accounting records being evaded. Furthermore, we focus only on the preparation of the consolidated balance sheet in the case of some hypothetical groups of companies.
\end{abstract}

\section{Keywords}

group of companies; consolidation techniques; consolidated financial statements; consolidated balance sheet.

\section{JEL Classification \\ M41}

\section{Introduction}

The Romanian Dictionary defines the concept of "technique" as a set of procedures and skills specific to a certain field (www.dexonline.ro).

Consolidated accounting, as a branch of financial accounting applied to group of companies, uses, as an instrument to accomplish its goal (preparation and presentation of consolidated financial statements), a so-called consolidation technique.

Therefore, consolidation technique refers to a set of procedures and skills used, especially, to prepare and present consolidated financial statements.

The first Romanian regulations related to consolidated accounting, approved by O.M.F. no. 772/2.000, stipulate two consolidation techniques, namely phased consolidation and direct consolidation (O.M.F. no. 772/2.000, art. 60).

Some authors mention two others consolidation techniques: one based on modular consolidation and another one based on fluctuations methods (Feleagă and Ionaşcu, 1998, pp. 686-687).

Modular consolidation technique consists in modular division of subsidiaries' financial statements, after which, these are regrouped, according to group's management strategy, by activity type, geographical area, production sector etc.

The technique based on fluctuations methods consists in the integration of previous consolidation data with current consolidation data, which allows solving two problems at once: evaluation of consolidation area year by year and accountancy of consolidation operations specific to current year. 
Consolidation techniques are applicable to complex groups (Figure 1) which are characterized also by indirect affinities between parent company and its subsidiaries.

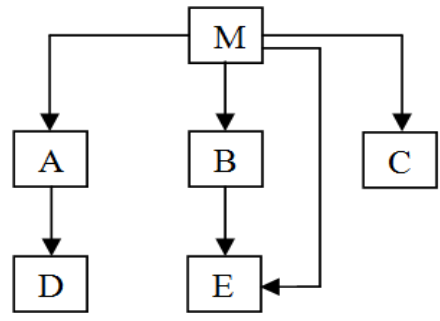

\section{Figure 1 Group of companies with a complex structure}

Source: Own processing

Consolidation techniques are applied together with consolidation methods, both pursuing the same objective: preparation and presentation of consolidated financial statements.

The following, we present the main characteristics of both consolidation techniques stipulated by the Romanian regulations.

\section{Phased consolidation technique}

According to phased consolidation's rules, consolidated financial statements are prepared for each subgroup of the group of entities applying, at each level, the appropriate consolidation method (according to control percent).

The first subgroup includes the entity (ies) that is (are) placed at the end of the affiliations chain (according to affiliations' flow chart) and its (their) parent entity. The subgroup's parent entity, in this case, is the very next entity (according to affiliations' flow chart) towards the parent entity of the entire group.

The consolidated financial statements of the next subgroup are prepared based on last subgroup's consolidated financial statements and the individual financial statements of the next parent entity and so on towards parent entity of the entire group. At this final level the consolidated financial statements of the entire group are prepared.

Thus, in Figure 1, at the first consolidation level, the D and E entities are consolidated within their parent entity namely A for D and B for E. Next level is consolidation of these two subgroups together with $\mathrm{C}$ entity within the $\mathrm{M}$ entity.

In preparation of consolidated financial statements of each subgroup they are used the participation (interest) percent owned by the parent company of that subgroup in the consolidated entity (ies), while the consolidation method depends on the control percent owned by the parent company of the entire group in the consolidated entity (ies).

\section{Direct consolidation technique}

Direct consolidation consists in consolidation of each subsidiary directly within the parent company of the group. Thus, a single set of consolidated financial statements is prepared.

For that purpose, the shareholders' equities of each subsidiary are divided between the parent company and minority shareholders (non-controlling interest) based on their participation percent in each subsidiary. However, when eliminate the carrying amount of investment in each subsidiary they are used the participation percent of 
both, the parent company of group and the minority shareholders, in the entity that owns the investment that are eliminated. Therefore, when the parent company owns indirectly the investment, the participation percents, used in either case, are different. In Figure 1, the A, B, C, D and E entities are directly consolidated within the parent company. When divide the shareholders' equity of D and E entities they are used the participation percent owned in these entities by both, $\mathrm{M}$ company and minority shareholders. Instead, when eliminate the carrying amount of A's and B's investments in $\mathrm{D}$ and $\mathrm{E}$, they are used the participation percent of both, M company and minority shareholders, owned in A and B entities.

\section{Phased consolidation versus direct consolidation}

In this section, we present, comparatively, some characteristics of both consolidation techniques together with their main advantages and disadvantages (Table 1).

Table 1 Phased consolidation versus direct consolidation

\begin{tabular}{|c|c|c|}
\hline Characterization criteria & Phased consolidation & Direct consolidation \\
\hline 1. Goal & $\begin{array}{l}\text { Preparation and presentation of } \\
\text { the annual consolidated } \\
\text { financial statements. }\end{array}$ & $\begin{array}{l}\text { Preparation and presentation of } \\
\text { the annual consolidated } \\
\text { financial statements. }\end{array}$ \\
\hline 2. Applicability area & $\begin{array}{l}\text { Small and medium groups of } \\
\text { companies; the groups flow } \\
\text { charts are simple and contain at } \\
\text { least two dependency levels. }\end{array}$ & $\begin{array}{l}\text { Small, medium and large groups } \\
\text { of companies; the groups flow } \\
\text { charts are complex and very } \\
\text { complex and contain at least two } \\
\text { dependency levels. }\end{array}$ \\
\hline 3. Procedure & $\begin{array}{l}\text { Consolidation based on multiple } \\
\text { levels in accord with group's } \\
\text { flow chart; at each level one or } \\
\text { more subgroups are constituted } \\
\text { and for each subgroup the } \\
\text { consolidated financial } \\
\text { statements are prepared. }\end{array}$ & $\begin{array}{l}\text { Direct consolidation of each } \\
\text { subsidiary within the parent } \\
\text { company, whatever the number } \\
\text { of dependency levels; a single } \\
\text { set of consolidated financial } \\
\text { statements is prepared. }\end{array}$ \\
\hline 4. Principles & $\begin{array}{l}\text { Consolidations start with the } \\
\text { entity placed at the end of the } \\
\text { affiliations chain (according } \\
\text { with affiliations' flow chart) and } \\
\text { continue, consecutively, until } \\
\text { the parent entity of the entire } \\
\text { group is one of the consolidated } \\
\text { entities. }\end{array}$ & $\begin{array}{l}\text { The order of consolidations is } \\
\text { not essential. }\end{array}$ \\
\hline 5. Instruments & $\begin{array}{l}\text { At each consolidation level, the } \\
\text { participation (interest) percent } \\
\text { owned by the parent company of } \\
\text { each subgroup in the } \\
\text { consolidated entity (ies). }\end{array}$ & $\begin{array}{l}\text { The participation (interest) } \\
\text { percent owned by the parent } \\
\text { company of the entire group in } \\
\text { each consolidated entity, } \\
\text { regardless of dependency level. }\end{array}$ \\
\hline $\begin{array}{l}\text { 6. Distribution } \\
\text { shareholders' equities }\end{array}$ & $\begin{array}{l}\text { At the level of each subgroup, } \\
\text { according to participation } \\
\text { percent in consolidated entity, } \\
\text { between subgroup's parent } \\
\text { entity and minority shareholders } \\
\text { (and others entities within the } \\
\text { consolidation area, but out of } \\
\text { subgroup). }\end{array}$ & $\begin{array}{l}\text { Between the parent company of } \\
\text { the entire group and minority } \\
\text { shareholders, according to their } \\
\text { participation percents in } \\
\text { consolidated entity. }\end{array}$ \\
\hline
\end{tabular}




\begin{tabular}{|c|c|c|}
\hline $\begin{array}{l}\text { 7. Distribution of carrying } \\
\text { amount of the investment } \\
\text { (together with their } \\
\text { elimination) }\end{array}$ & $\begin{array}{l}\text { At the level of each subgroup, } \\
\text { its entire value is attributed to } \\
\text { parent entity of subgroup, as a } \\
\text { consequence of direct } \\
\text { affiliation. }\end{array}$ & $\begin{array}{l}\text { At the level of group, between } \\
\text { the parent company of group } \\
\text { and the minority shareholders, } \\
\text { according to their participation } \\
\text { percent in the entity that owns } \\
\text { the investment that is } \\
\text { eliminated. }\end{array}$ \\
\hline 8. Advantages & $\begin{array}{l}\text { - Allow to divide the financial } \\
\text { information within the group as } \\
\text { a result of preparation the } \\
\text { consolidated financial } \\
\text { statements at the level of each } \\
\text { subgroup. }\end{array}$ & $\begin{array}{l}\text { - Provide, directly, promptly and } \\
\text { low-priced information about } \\
\text { the financial position, } \\
\text { performance and changes in } \\
\text { financial position of group of } \\
\text { companies; } \\
\text { - Allow to better control the } \\
\text { distribution of shareholders' } \\
\text { equities between the parent } \\
\text { company of the group and } \\
\text { minority shareholders. }\end{array}$ \\
\hline 9. Disadvantages & $\begin{array}{l}\text { Imply: } \\
\text { - high volume of work for } \\
\text { preparation the consolidated } \\
\text { financial statements of each } \\
\text { subgroup; } \\
\text { - high cost; } \\
\text { - non-applicability for all types } \\
\text { of groups of entities. }\end{array}$ & $\begin{array}{l}\text { It does not allow: } \\
\text { - analysis within the group } \\
\text { which can satisfy the objectives } \\
\text { of internal management (provide } \\
\text { information to make good } \\
\text { decisions); } \\
\text { - group segmentation by activity } \\
\text { type, geographical area etc. }\end{array}$ \\
\hline
\end{tabular}

Source: Own processing based on literature (Pitulice, 2007, pp. 116-130; Bogdan et. al., 2011, pp. 89-98; Feleagă and Ionaşcu, 1998, pp. 686-687; Popa et al., 2007, pp. 367-386; Deju, 2013, pp. 91-105; Săcărin, 2001, pp. 38-48)

Whatever the selected technique, the consolidated financial statements are the same (as we show in the following).

\section{Studies regarding the applicability of consolidation techniques}

In this section, we present the applicability of consolidation techniques preparing the consolidated balance sheet of some hypothetical groups of companies (the same rules are applied also when prepare income statement). Considering this work regards only the technical part of consolidated accounting, we ignore the accounting records.

As a consequence, to simplify the following examples, we assume that the parent company has owned subsidiaries' shares since their incorporation. Therefore full subsidiaries' retained earnings are post-acquisition, and between entities of the group there are no transactions.

Note 1: We use the report form of the balance sheet but in a very simplified version, considering that, regardless of the items number of balance sheet, the rules of consolidation techniques and of consolidation methods remain the same.

\section{Example 1}

The "M" company has owned $80 \%$ shares of "A" company and the "A" company has owned $40 \%$ of "B" company.

Below there are the separate financial statements, as at 31 December N, of these three entities that compose the group. 
Table 2 Separate financial statements of " $M$ ", " $A$ " and " $B$ " entities

\begin{tabular}{|l|r|r|r|}
\hline \multicolumn{1}{|c|}{ Balance sheet items } & \multicolumn{1}{c|}{ M } & \multicolumn{1}{c|}{ A } & \multicolumn{1}{c|}{ B } \\
\hline Shares in affiliated entities & 160 & - & - \\
Investments in associates & - & 40 & - \\
Diverse assets & 440 & 410 & 200 \\
\hline Total assets & $\mathbf{6 0 0}$ & $\mathbf{4 5 0}$ & $\mathbf{2 0 0}$ \\
\hline Share capital & 200 & 200 & 100 \\
Reserves & 100 & 100 & 20 \\
Profit (loss) for the period & 50 & 100 & 70 \\
\hline Shareholders' equity & 350 & 400 & 190 \\
Liabilities & 250 & 50 & 10 \\
\hline Total equity and liabilities & $\mathbf{6 0 0}$ & $\mathbf{4 5 0}$ & $\mathbf{2 0 0}$ \\
\hline
\end{tabular}

The chart of group " $\mathrm{M}$ " is as below:

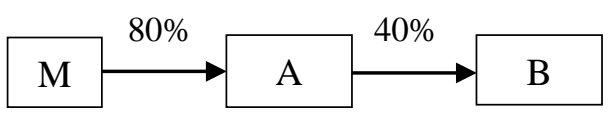

The first step in preparation the consolidated balance sheet is to establish how the M company controls (mostly through voting power) the others two companies. For that purpose they are calculated the voting power or the, so-called, control percent owned in each subsidiary $(\mathrm{CP})$ on the basis of is established the consolidation method.

Thus:

$-\mathrm{CP}_{\mathrm{M} \rightarrow \mathrm{A}}=80 \% \rightarrow$ requires Global integration method

$-\mathrm{CP}_{\mathrm{M} \rightarrow \mathrm{B}}=40 \% \rightarrow$ requires Equity method

\section{A. Preparation of balance sheet using phased consolidation technique}

$\mathbf{1}^{\text {st }}$ consolidation level: Consolidation of " $\mathrm{B}$ " entity within the " $\mathrm{A}$ " entity

The participation (interest) percent (PP) used for this consolidation level is:

$\mathrm{PP}_{\mathrm{A} \rightarrow \mathrm{B}}=40 \%$

Table 3 Consolidated balance sheet of subgroup " $A$ "

\begin{tabular}{|l|r|}
\hline \multicolumn{1}{|c|}{ Balance sheet items } & \multicolumn{1}{c|}{ Amount } \\
\hline Investments accounted for using the equity method (40\% x 190) & 76 \\
Diverse assets & 410 \\
\hline Total assets & $\mathbf{4 8 6}$ \\
\hline Share capital & 200 \\
Consolidated reserves $(100+40 \% \times 20)$ & 108 \\
Consolidated profit (loss) for the period $(100+40 \% \times 70)$ & 128 \\
\hline Shareholders' equity & 436 \\
Liabilities & 50 \\
\hline Total equity and liabilities & $\mathbf{4 8 6}$ \\
\hline
\end{tabular}

$2^{\text {nd }}$ consolidation level: Consolidation of subgroup "A" within the parent entity " $M$ ".

The participation (interest) percent (PP) used for this consolidation level is:

$\mathrm{PP}_{\mathrm{M} \rightarrow \mathrm{A}}=80 \%$ 
Table 4 Consolidated balance sheet of group "M"

\begin{tabular}{|l|r|}
\hline \multicolumn{1}{|c|}{ Balance sheet items } & \multicolumn{1}{|c|}{ Amount } \\
\hline Investments accounted for using the equity method & 76 \\
Diverse assets (410 + 440) & 850 \\
\hline Total assets & $\mathbf{9 2 6}$ \\
\hline Share capital & 200 \\
Consolidated reserves (100 + 80\% x 108) & 186.4 \\
Consolidated profit (loss) for the period (50 + 80\% x 128) & 152.4 \\
Non-controlling interests, of which: & 87.2 \\
- Non-controlling interests - profit (loss) of the period (20\% x 128) & 25.6 \\
- Non-controlling interests - other own capital (20\% x 308) & 61.6 \\
\hline Shareholders' equity & 626 \\
Liabilities (250 + 50) & 300 \\
\hline Total equity and liabilities & $\mathbf{9 2 6}$ \\
\hline
\end{tabular}

B. Preparation of balance sheet using direct consolidation technique

In order to prepare the consolidated balance sheet using direct consolidation technique, we use two intermediate tables by means of which we divide the shareholders' equities of each subsidiary between the parent company and minority shareholders (non-controlling interest) based on their participation percent in each subsidiary. Also, when eliminate the carrying amount of investment in each subsidiary, we divide it between the parent company and minority shareholders, according to their participation percent in entity who owns the investment that is eliminated, together with the elimination of parent's portion of share capital of each subsidiary.

The participation (interest) percents (PP) used for each consolidation are:

$1^{\text {st }}$ consolidation: $\mathrm{PP}_{\mathrm{M} \rightarrow \mathrm{A}}=80 \%$;

$2^{\text {nd }}$ consolidation: $\mathrm{PP}_{\mathrm{M} \rightarrow \mathrm{B}}=32 \%$

Table 5 Distribution of shareholders" equity of " $A$ " entity

\begin{tabular}{|c|l|r|r|r|}
\hline No. & \multicolumn{1}{|c|}{ Shareholders' equity } & Total & \multicolumn{1}{|c|}{$\begin{array}{c}\text { M's interest } \\
\mathbf{( 8 0 \% )}\end{array}$} & $\begin{array}{l}\text { Non-controlling } \\
\text { interests (20\%) }\end{array}$ \\
\hline 1 & Share capital & 200 & 160 & 40 \\
\hline 2 & Reserves & 100 & 80 & 20 \\
\hline 3 & Profit (loss) for the period & 100 & 80 & 20 \\
\hline $\mathbf{4}$ & Total equity (1+2 +3) & $\mathbf{4 0 0}$ & $\mathbf{3 2 0}$ & $\mathbf{8 0}$ \\
\hline 5 & Elimination of investment in A entity & 160 & 160 & - \\
\hline $\mathbf{6}$ & Distribution $(\mathbf{4}$ - 5) & $\mathbf{2 4 0}$ & $\mathbf{1 6 0}$ & $\mathbf{8 0}$ \\
\hline
\end{tabular}

Table 6 Distribution of shareholders' equity of "B" entity

\begin{tabular}{|r|l|r|r|r|r|}
\hline No. & Shareholders' equity & Total & \multicolumn{1}{|c|}{$\begin{array}{c}\text { A's } \\
\text { interest } \\
\mathbf{( 4 0 \% )}\end{array}$} & $\begin{array}{l}\text { M's interest } \\
\text { in B through } \\
\text { A (80\%) }\end{array}$ & $\begin{array}{l}\text { Non-controlling } \\
\text { interests in B } \\
\text { through A (20\%) }\end{array}$ \\
\hline 1 & Share capital & 100 & 40 & 32 & 8 \\
\hline 2 & Reserves & 20 & 8 & 6.4 & 1.6 \\
\hline 3 & Profit (loss) for the period & 70 & 28 & 22.4 & 5.6 \\
\hline $\mathbf{4}$ & Total equity (1+2 +3) & $\mathbf{1 9 0}$ & $\mathbf{7 6}$ & $\mathbf{6 0 . 8}$ & $\mathbf{1 5 . 2}$ \\
\hline 5 & $\begin{array}{l}\text { Elimination of investment } \\
\text { in B entity }\end{array}$ & 40 & 40 & 32 & $\mathbf{7 . 2}$ \\
\hline $\mathbf{6}$ & Distribution (4-5) & $\mathbf{1 5 0}$ & $\mathbf{3 6}$ & $\mathbf{2 8 . 8}$ & \\
\hline
\end{tabular}


Note 2: The parent entity ("M") does not control its investee in "B" entity. Therefore, she is entitled (according with her participation percent in "A") only to "A"'s portion of "B"'s equities.

\section{Table 7 Consolidated balance sheet of group "M"}

\begin{tabular}{|l|r|}
\hline \multicolumn{1}{|c|}{ Balance sheet items } & \multicolumn{1}{|c|}{ Amount } \\
\hline Investments accounted for using the equity method (40\% x 190) & 76 \\
Diverse assets (410 + 440) & 850 \\
\hline Total assets & $\mathbf{9 2 6}$ \\
\hline Share capital & 200 \\
Consolidated reserves $(100+80+6.4)$ & 186.4 \\
Consolidated profit (loss) for the period $(50+80+22.4)$ & 152.4 \\
Non-controlling interests, of which: & 87.2 \\
- Non-controlling interests - profit (loss) of the period (20+5.6) & 25.6 \\
- Non-controlling interests - other own capital $(40+20+1.6)$ & 61.6 \\
\hline Shareholders' equities & 626 \\
Liabilities (250 + 50) & 300 \\
\hline Total equity and liabilities & $\mathbf{9 2 6}$ \\
\hline
\end{tabular}

\section{Example 2}

The " $M$ " company has owned $25 \%$ shares of "A" company and $60 \%$ shares of "B" company. "A" company has owned $30 \%$ of "B" company.

Below there are the separate financial statements, as at 31 December $\mathrm{N}$, of these three entities that compose the group.

Table 8 Separate financial statements of "M", "A" and "B" entities

\begin{tabular}{|l|r|r|r|}
\hline \multicolumn{1}{|c|}{ Balance sheet items } & M & \multicolumn{1}{c|}{ A } & \multicolumn{1}{c|}{ B } \\
\hline Shares in affiliated entities (M in B) & 60 & & \\
Investments in associates & & & - \\
M in A & - & & \\
A in B & 490 & 40 & - \\
Diverse assets & $\mathbf{6 0 0}$ & $\mathbf{4 5 0}$ & $\mathbf{2 0 0}$ \\
\hline Total assets & 200 & 200 & 100 \\
\hline Share capital & 100 & 100 & 20 \\
Reserves & 50 & 100 & 70 \\
Profit (loss) for the period & 350 & 400 & 190 \\
\hline Shareholders' equity & 250 & 50 & 10 \\
Liabilities & $\mathbf{6 0 0}$ & $\mathbf{4 5 0}$ & $\mathbf{2 0 0}$ \\
\hline Total equity and liabilities & & & \\
\hline
\end{tabular}

The chart of group "M" is as below:

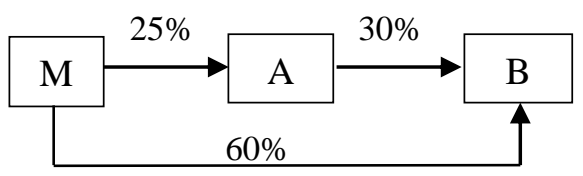

Thus:

$-\mathrm{CP}_{\mathrm{M} \rightarrow \mathrm{A}}=25 \% \rightarrow$ requires Equity method

$-\mathrm{CP}_{\mathrm{M} \rightarrow \mathrm{B}}=60 \% \rightarrow$ requires Global integration method 
A. Preparation of balance sheet using phased consolidation technique

$\mathbf{1}^{\text {st }}$ consolidation level: Consolidation of " $\mathrm{B}$ " entity within the " $\mathrm{A}$ " entity

The participation (interest) percent (PP) used for this consolidation level is:

$\mathrm{PP}_{\mathrm{A} \rightarrow \mathrm{B}}=30 \%$

Table 9 Consolidated balance sheet of subgroup " $A$ "

\begin{tabular}{|l|r|}
\hline \multicolumn{1}{|c|}{ Balance sheet items } & Amount \\
\hline Diverse assets (420 + 200) & 620 \\
\hline Total assets & $\mathbf{6 2 0}$ \\
\hline Share capital & 200 \\
Consolidated reserves (100 + 30\% x 20) & 106 \\
Consolidated profit (loss) for the period (100 + 30\% x 70) & 121 \\
Non-controlling interests, of which: & 19 \\
- Non-controlling interests - profit (loss) of the period (10\% x 70) & 7 \\
- Non-controlling interests - other own capital (10\% x 120) & 12 \\
M's direct interests in B, of which: & 114 \\
- M's interests - profit (loss) of the period (60\% x 70) & 42 \\
- M's interests - other own capital (60\% x 120) & 72 \\
\hline Shareholders' equities & 560 \\
Liabilities (50 + 10) & 60 \\
\hline Total equity and liabilities & $\mathbf{6 2 0}$ \\
\hline
\end{tabular}

Note 3: The " $M$ " interest in "B" is separately mentioned, as it can not be considered a non-controlling interest.

$2^{\text {nd }}$ consolidation level: Consolidation of subgroup "A" within the parent entity " $M$ ".

The participation (interest) percent (PP) used for this consolidation level is:

$\mathrm{PP}_{\mathrm{M} \rightarrow \mathrm{A}}=25 \%$

Table 10 Consolidated balance sheet of group " $\mathrm{M}$ "

\begin{tabular}{|l|r|}
\hline \multicolumn{1}{|c|}{ Balance sheet items } & \multicolumn{1}{c|}{ Amount } \\
\hline Investments accounted for using the equity method $(25 \% \times 427)^{1}$ & 106.75 \\
Diverse assets $(490+60 \% \times 200)$ & 610 \\
\hline Total assets & $\mathbf{7 1 6 . 7 5}$ \\
\hline Share capital & 200 \\
Consolidated reserves (100 + 25\% x 106 +60\% x 20) & 138.5 \\
Consolidated profit (loss) for the period (50+25\% x 121+60\% x 70) & 122.25 \\
\hline Shareholders' equities & 460.75 \\
Liabilities (250 + 60\% x 10) & 256 \\
\hline Total equity and liabilities & $\mathbf{7 1 6 . 7 5}$ \\
\hline
\end{tabular}

Note 4: "M" directly owns an interest in "B" which affects the assets, the equity and the liabilities of group.

\footnotetext{
1427 represents the total equity of subgroup "A", disregarding non-controlling interests and "M"'s interests.
} 


\section{B. Preparation of balance sheet using direct consolidation technique}

The participation (interest) percents (PP) used for each consolidation are:

$1^{\text {st }}$ consolidation: $\mathrm{PP}_{\mathrm{M} \rightarrow \mathrm{A}}=25 \%$;

$2^{\text {nd }}$ consolidation: $\mathrm{PP}_{\mathrm{M} \rightarrow \mathrm{B}}=67.5 \%$

Table 11 Distribution of shareholders' equity of " $A$ " entity

\begin{tabular}{|c|l|r|r|}
\hline No. & \multicolumn{1}{|c|}{ Shareholders' equity } & \multicolumn{1}{c|}{ Total } & $\begin{array}{c}\text { M's interest } \\
\text { (25\%) }\end{array}$ \\
\hline 1 & Share capital & 200 & 50 \\
\hline 2 & Reserves & 100 & 25 \\
\hline 3 & Profit (loss) for the period & 100 & 25 \\
\hline $\mathbf{4}$ & Total equity (1+ 2+3) & $\mathbf{4 0 0}$ & $\mathbf{1 0 0}$ \\
\hline 5 & Elimination of investment in A entity & $\mathbf{3 5 0}$ & 50 \\
\hline $\mathbf{6}$ & Distribution (4 - 5) & $\mathbf{5 0}$ \\
\hline
\end{tabular}

Table 12 Distribution of shareholders' equity of "B" entity

\begin{tabular}{|c|l|r|r|r|r|}
\hline No. & \multicolumn{1}{|c|}{ Shareholders' equity } & Total & \multicolumn{1}{c|}{$\begin{array}{c}\text { M's } \\
\text { interest } \\
(\mathbf{6 0 \%})\end{array}$} & \multicolumn{1}{c|}{$\begin{array}{c}\text { A's } \\
\text { interest } \\
(\mathbf{3 0 \%})\end{array}$} & $\begin{array}{c}\text { M's interest } \\
\text { in B through } \\
\text { A (25\%) }\end{array}$ \\
\hline 1 & Share capital & 100 & 60 & 30 & 7.5 \\
\hline 2 & Reserves & 20 & 12 & 6 & 1.5 \\
\hline 3 & Profit (loss) for the period & 70 & 42 & 21 & 5.25 \\
\hline $\mathbf{4}$ & Total equity (1+2+3) & $\mathbf{1 9 0}$ & $\mathbf{1 1 4}$ & $\mathbf{5 7}$ & $\mathbf{1 4 . 2 5}$ \\
\hline 5 & Elimination of investment in & 90 & 60 & 30 & 7.5 \\
\cline { 2 - 6 } & B entity & 30 & - & 30 & 7.5 \\
& - A in B & 60 & 60 & - & - \\
\hline $\mathbf{6}$ & - Min B & $\mathbf{1 0 0}$ & $\mathbf{5 4}$ & $\mathbf{2 7}$ & $\mathbf{6 . 7 5}$ \\
\hline
\end{tabular}

Table 13 Consolidated balance sheet of group "M"

\begin{tabular}{|l|r|}
\hline \multicolumn{1}{|c|}{ Balance sheet items } & \multicolumn{1}{|c|}{ Amount } \\
\hline Investments accounted for using the equity method $(25 \%$ x $400+7.5 \%$ x & 106.75 \\
$190-7.5)$ & 610 \\
Diverse assets $(490+60 \%$ x 200) & $\mathbf{7 1 6 . 7 5}$ \\
\hline Total assets & 200 \\
\hline Share capital & 138,5 \\
Consolidated reserves $(100+25+12+1.5)$ & 122.25 \\
Consolidated profit (loss) for the period (50+25+42+5.25) & 460.75 \\
\hline Shareholders' equities & 256 \\
Liabilities (250 + 60\% x 10) & $\mathbf{7 1 6 . 7 5}$ \\
\hline Total equity and liabilities & \\
\hline
\end{tabular}

\section{Conclusions}

Preparation of the consolidated financial statements, in the case of complex groups of societies, is a technical issue of the parent entity of the entire group, as we show in this article.

However, preparation of the consolidated financial statements is based on accounting records. In this article we ignore them and we focuses on the technical side of the 
consolidated accounting. In a following work, we will approach also the accountant side of consolidated accounting.

Consolidation techniques are applicable in the case of complex group of societies. In this article we have applied two consolidation techniques that are recognized in Romanian regulations, namely phased consolidation and direct consolidation.

The direct consolidation technique is mostly used in the case of group of companies with a complex and very complex flow chart because it promptly allows preparing the consolidated financial statements only at the level of parent company of the group.

The phased consolidation technique is applied, especially, in the case of group of companies with a simple flow chart, this technique requiring the preparation of consolidated financial statements at each dependency level.

In a particular case of group of entities, whatever the consolidation technique that they are applied, the consolidated financial statements of the group are exactly the same.

\section{References}

Bogdan, V. et al. (2011), Raportarea financiară la nivelul grupurilor de societăţi repere contemporane, Bucureşti, Editura Economică.

Deju, M. (2013), Contabilitatea consolidată - curs universitar, Bacău, Editura Alma Mater.

Feleagă, N., Ionaşcu, I. (1998), Tratat de contabilitate, vol. I-II, Bucureşti, Editura Economică.

Pitulice, C. (2007), Teorie şi practică privind grupurile de societăţi şi situaţiile financiare consolidate, Ploieşti, Editura Contaplus.

Popa, A.F. et al. (2007), Studii practice privind aplicarea Standardelor Internaţionale de Raportare Financiară, Ploieşti, Editura Contaplus.

Săcărin, M. (2001), Contabilitatea grupurilor multinaţionale, Bucureşti, Editura Economică.

O.M.F. nr. 772/2000 de aprobare a Normelor privind consolidarea conturilor, published in M. Of. Partea I nr. 374 din 11 august 2000, repealed.

www.dexonline.ro. 